\title{
COMMENTARY
}

\section{Influenza Casts a Lung Shadow}

\author{
Xavier De Luna and Kevan L. Hartshorn
}

From the Department of Medicine, Section of Hematology and Oncology, Boston University School of Medicine, Boston, Massachusetts

Influenza A viruses (IAVs) are a major cause of infectious morbidity and mortality worldwide. IAV is highly prone to genomic change over time. Yearly epidemics of IAV result from accumulated point mutations in viral envelope proteins such that adaptive immune responses to prior strains are no longer protective. IAV pandemics result from acquisition of whole new genome segments from animal viruses (generally porcine or avian strains). Although most infected people recover uneventfully, mortality from IAV remains a challenge in certain vulnerable groups, including those at extremes of age, with lung disease, pregnancy, heart disease, or diabetes. However, IAV can also cause mortality in young, otherwise healthy adults. This has been more evident during pandemics of IAV, but also occurs during seasonal epidemics. IAV can kill by either causing diffuse lung injury or altering host defense against secondary bacterial infection. Often bacterial super-infections occur in patients partially recovered from the primary IAV infection.

Murine models have provided important insights into the causes of diffuse lung injury or secondary bacterial pneumonia. Despite having a limited genome (eight main gene segments encoding approximately ten to eleven proteins) as compared with DNA viruses, IAV causes a remarkably complex innate immune response. ${ }^{1}$ One of the surprising features of IAV infection is that pathological and immunological changes in the lung persist long after clearance of the virus. ${ }^{2}$ The article by Pociask et $\mathrm{al}^{3}$ in this issue of The American Journal of Pathology provides important new insights into the mechanism of these prolonged effects. ${ }^{3}$ Although there are clearly important differences between IAV infection of mice and humans, the bacterial superinfection model in mice has many parallels to human infections. In both cases the greatest period of vulnerability appears to be at some delay after the initial viral infection (approximately 7 days post viral infection) and to lead to marked worsening of the bacterial pneumonia. Alcorn et al (along with other groups) have made major contributions to our understanding of the causes of post IAV bacterial super-infection. ${ }^{4-7}$ The breakdown in anti-bacterial defense is likely multifactorial, but virus-induced Type I interferon generation leading to suppression of Type 17 immunity is one critical mechanism.

The article by Pociask et $\mathrm{al}^{3}$ shows that important changes in the lung persist up to two months after viral infection. Day 21 post viral infection was studied most extensively. At this time point, there is ongoing inflammation based on elevated inflammatory cell counts and increased CD4, CD8, and interferon- $\gamma$ positive lymphocytes in bronchoalveolar lavage fluid. This ongoing inflammation is present despite recovery of weight by the mice and essentially undetectable viral loads in the lung. Significant histopathological changes in the lung are also present including epithelial metaplasia and airspace occlusion, and these changes persist up to 60 days post infection. Of interest, despite the varied changes present at day 21 , the mice no longer show increased susceptibility to Staphylococcus aureus superinfection based on bacterial loads. Some of the immune changes seen during bacterial superinfection at earlier time points (eg, day 7 post viral infection) persist, including depression in IL-17 generation and neutrophil influx (as compared with mice infected with $S$. aureus without prior viral infection). However, the mice infected with $S$. aureus 21 days after viral infection have strongly increased IL-22 production and no longer have depressed Reg $3 b$ expression.

IL-22 has been shown to reduce inflammation and to protect against bacterial superinfection post IAV infection. ${ }^{8,9}$ IL-22 promotes antimicrobial peptide production in the lung, which Dr. Alcorn's laboratory have shown to

\footnotetext{
Supported by NIH grant RO1 HL069031 (K.L.H.).

Accepted for publication January 26, 2017.

Disclosures: None declared.

Address correspondence to Kevan L. Hartshorn, M.D., Boston University School of Medicine, EBRC 414, 650 Albany St., Boston, MA 02118.

E-mail: khartsho@bu.edu
} 
be depressed at day 7 post IAV infection. ${ }^{10}$ Based on transcriptomic analysis in the current study, several antimicrobial peptides show increased expression at day 21 and 35 , and this may contribute to the ability of these mice to control S. aureus super-infection despite reduced neutrophil influx. Another beneficial effect of IL-22 in the context of IAV infection is promotion of lung repair. ${ }^{11}$

Reg $3 b$ is an anti-microbial lectin which has been studied extensively for its role in protection against bacterial infection in the gut. ${ }^{12}$ Reg $3 \mathrm{~b}$ can bind bacteria, but, unlike the related protein Reg3g, it has not been clearly demonstrated to work through direct bactericidal activity. Rather, it has been shown to inhibit bacterial translocation and to act as an alarmin, recruiting other inflammatory cells, including neutrophils. In an intestinal model of inflammation (dextran-induced colitis), Reg3b induced recruitment of IL-22-secreting neutrophils resulting in decreased inflammation and improved epithelial reconstitution. ${ }^{12}$

Another key finding of the paper by Pociask et $\mathrm{al}^{3}$ include demonstration of marked lung transcriptomic changes at days 21 and 35 post IAV including genes associated with endoplasmic reticulum stress which was confirmed at the level of protein expression as well (ie, increased CCAATenhancer binding protein homologous protein and activating transcription factor staining in the lung). Other up-regulated genes at days 21 and 35 include cytokines and other inflammatory mediators, antimicrobial peptides, but also genes associated with tissue remodeling and repair. These findings correlate with the bronchoalveolar lavage and histological findings. ${ }^{3}$ The overall picture derived from the transcriptomic findings is one of prolonged inflammation and epithelial injury long after viral clearance.

Finally, important findings were obtained by use of miRNA microarray. Specifically, miR-155 expression was increased, and expression of 26 known target genes for miR155 were differentially modulated (some increased and others decreased) post IAV infection. miR-155 has previously been shown to be increased post IAV infection in mice and to worsen outcome of post-IAV bacterial super-infection. ${ }^{13}$ miR-155 promotes lung inflammation in response to LPS in part by inhibiting SOCs expression, ${ }^{14}$ to promote lung fibrosis ${ }^{15}$ and lung cancer progression. ${ }^{16}$ In the present study, ${ }^{3}$ miR-155 was found to worsen the extent of weight loss, and the degree sustained lung injury (histology) and ER stress at day 21. This was demonstrated using miR-155 knockout mice. Absence of miR-155 did not affect viral loads, inflammatory cell infiltrates or most cytokines at day 7 or day 21 . Hence, miR-155 seemed to be mainly inhibiting lung reparative processes at the later stage post infection.

Overall, the paper by Posiask et $\mathrm{al}^{3}$ shows that IAV infection leads to prolonged changes in the lung well after apparent viral clearance and specifically highlights the potential role of lung repair mechanisms in successful recovery from IAV infection. It is tempting to speculate on potential treatment of severe IAV infection with combinations of antivirals and measures to promote lung repair including IL-22 or Reg3b or inhibitors of miR-155. A potential caveat to such an approach include the reports that miR-155 is protective versus Mycobacterium tuberculosis infection in mice. ${ }^{17}$ In addition, proteins known to accelerate lung epithelial proliferation might increase viral replication.

Another possible implication of the results is the consideration that the sustained changes seen after IAV infection could relate to its known ability to cause sometimes sustained worsening of lung function in patients with cystic fibrosis ${ }^{18}$ or chronic obstructive pulmonary disease. ${ }^{19,20}$ It must be noted that the findings by Pociask et $\mathrm{al}^{3}$ are in a well-defined mouse model using a highly mouse adapted IAV strain, hence, ultimately their relevance in models more closely resembling human infection (or in human infection) will need to be determined. An additional line of inquiry will be to determine the effect of other viral strains or specific viral components on the sustained lung injuries caused by IAV.

\section{References}

1. Tripathi S, White MR, Hartshorn KL: The amazing innate immune response to influenza A virus infection. Innate Immun 2015, 21:73-98

2. Didierlaurent A, Goulding J, Patel S, Snelgrove R, Low L, Bebien M, Lawrence T, van Rijt LS, Lambrecht BN, Sirard JC, Hussell T: Sustained desensitization to bacterial Toll-like receptor ligands after resolution of respiratory influenza infection. J Exp Med 2008, 205:323-329

3. Pociask DA, Robinson KM, Chen K, McHugh KJ, Clay ME, Huang GT, Benos PV, Janssen-Heininger YM, Kolls JK, Anathy V, Alcorn JF: Epigenetic and transcriptomic regulation of lung repair during recovery from influenza infection. Am J Pathol 2017:851-863

4. Kudva A, Scheller EV, Robinson KM, Crowe CR, Choi SM, Slight SR, Khader SA, Dubin PJ, Enelow RI, Kolls JK, Alcorn JF: Influenza A inhibits Th17-mediated host defense against bacterial pneumonia in mice. J Immunol 2011, 186:1666-1674

5. Rynda-Apple A, Robinson KM, Alcorn JF: Influenza and bacterial superinfection: illuminating the immunologic mechanisms of disease. Infect Immun 2015, 83:3764-3770

6. Lee B, Robinson KM, McHugh KJ, Scheller EV, Mandalapu S, Chen C, Di YP, Clay ME, Enelow RI, Dubin PJ, Alcorn JF: Influenzainduced type I interferon enhances susceptibility to gram-negative and gram-positive bacterial pneumonia in mice. Am J Physiol Lung Cell Mol Physiol 2015, 309:L158-L167

7. Robinson KM, McHugh KJ, Mandalapu S, Clay ME, Lee B, Scheller EV, Enelow RI, Chan YR, Kolls JK, Alcorn JF: Influenza A virus exacerbates Staphylococcus aureus pneumonia in mice by attenuating antimicrobial peptide production. J Infect Dis 2014, 209:865-875

8. Paget C, Ivanov S, Fontaine J, Renneson J, Blanc F, Pichavant M, Dumoutier L, Ryffel B, Renauld JC, Gosset P, Si-Tahar M, Faveeuw C, Trottein F: Interleukin-22 is produced by invariant natural killer T lymphocytes during influenza A virus infection: potential role in protection against lung epithelial damages. J Biol Chem 2012, 287:8816-8829

9. Ivanov S, Renneson J, Fontaine J, Barthelemy A, Paget C, Fernandez EM, Blanc F, De Trez C, Van Maele L, Dumoutier L, Huerre MR, Eberl G, Si-Tahar M, Gosset P, Renauld JC, Sirard JC, Faveeuw C, Trottein F: Interleukin-22 reduces lung inflammation during influenza A virus infection and protects against secondary bacterial infection. J Virol 2013, 87:6911-6924

10. Pociask DA, Scheller EV, Mandalapu S, McHugh KJ, Enelow RI, Fattman CL, Kolls JK, Alcorn JF: IL-22 is essential for lung epithelial repair following influenza infection. Am J Pathol 2013, 182:1286-1296

11. Kumar P, Thakar MS, Ouyang W, Malarkannan S: IL-22 from conventional NK cells is epithelial regenerative and inflammation protective during influenza infection. Mucosal Immunol 2012, 6:69-82 
12. van Ampting MT, Loonen LM, Schonewille AJ, Konings I, Vink C, Iovanna J, Chamaillard M, Dekker J, van der Meer R, Wells JM, Bovee-Oudenhoven IM: Intestinally secreted C-type lectin Reg3b attenuates salmonellosis but not listeriosis in mice. Infect Immun 2012, 80:1115-1120

13. Podsiad A, Standiford TJ, Ballinger MN, Eakin R, Park P, Kunkel SL, Moore BB, Bhan U: MicroRNA-155 regulates host immune response to postviral bacterial pneumonia via IL-23/IL-17 pathway. Am J Physiol Lung Cell Mol Physiol 2016, 310:L465-L475

14. Wang W, Liu Z, Su J, Chen WS, Wang XW, Bai SX, Zhang JZ, Yu SQ: Macrophage micro-RNA-155 promotes lipopolysaccharideinduced acute lung injury in mice and rats. Am J Physiol Lung Cell Mol Physiol 2016, 311:L494-L506

15. Christmann RB, Wooten A, Sampaio-Barros P, Borges CL, Carvalho CR, Kairalla RA, Feghali-Bostwick C, Ziemek J, Mei Y, Goummih S, Tan J, Alvarez D, Kass DJ, Rojas M, de Mattos TL, Parra E, Stifano G, Capelozzi VL, Simms RW, Lafyatis R: miR-155 in the progression of lung fibrosis in systemic sclerosis. Arthritis Res Ther 2016, 18:155
16. Xue X, Liu Y, Wang Y, Meng M, Wang K, Zang X, Zhao S, Sun X Cui L, Pan L, Liu S: MiR-21 and MiR-155 promote non-small cell lung cancer progression by downregulating SOCS1, SOCS6, and PTEN. Oncotarget 2016, 7:84508-84519

17. Iwai H, Funatogawa K, Matsumura K, Kato-Miyazawa M, Kirikae F, Kiga K, Sasakawa C, Miyoshi-Akiyama T, Kirikae T: MicroRNA-155 knockout mice are susceptible to Mycobacterium tuberculosis infection. Tuberculosis (Edinb) 2015, 95:246-250

18. Hendricks MR, Bomberger JM: Digging through the Obstruction: insight into the epithelial cell response to respiratory virus infection in patients with cystic fibrosis. J Virol 2016, 90:4258-4261

19. Caramori G, Ito K, Contoli M, Di Stefano A, Johnston SL, Adcock IM, Papi A: Molecular mechanisms of respiratory virus-induced asthma and COPD exacerbations and pneumonia. Curr Med Chem 2006, 13: $2267-2290$

20. Gorse GJ, O'Connor TZ, Young SL, Habib MP, Wittes J, Neuzil KM, Nichol KL: Impact of a winter respiratory virus season on patients with COPD and association with influenza vaccination. Chest 2006, 130: $1109-1116$ 